\title{
HUBUNGAN PELATIHAN DENGAN KINERJA PEGAWAI BADAN PENANGGULANGAN BENCANA DAERAH (BPBD) KOTA BANDAR LAMPUNG
}

\author{
Ahiruddin $^{(1)^{*}}$, Maria Elina ${ }^{(1)}$, Ja'a Taufikul Hulami ${ }^{(2)}$ \\ Fakultas Ekonomi niversitas Sang Bumi Ruwa Jurai \\ Mahasiswa Universitas Sang Bumi Ruwa Jurai \\ ahiruddin@fe.saburai.ac.id,maria.elina@fe.saburai.ac.id, jaatafikulhulami@gmail.com
}

\begin{abstract}
Abstrak. Tujuan penelitian untuk mengetahui hubungan pelatihan dengan kinerja pegawai Badan Penanggulangan Bencana Daerah (BPBD) Kota Bandar Lampung. Metode penelitian yang digunakan dalam penelitian ini menggunakan metode penelitian deskriptif kuantitatif . Dengan metode analisis menggunakan produk moment. Metode pengumpulan data yang digunakan berupa data primer dan data sekunder. Teknik pengumpulan data yang digunakan adalah observasi dan quisioner. Populasi yang digunakan dalam penelitian ini berjumlah 47 pegawai Badan Penanggulangan Bencana Daerah (BPBD) Kota Bandar Lampung Hasil pengujian hipotesis hubungan pelatihan dengan kinerja menunjukan bahwa nilai hubungan antara pelatihan dengan kinerja pegawai BPBD Kota Bandar Lampung sebesar 0,839. Artinya ada hubungan pelatihan dengan kinerja. Kemudian nilai keeratan hubungan pelatihan dan kinerja sebesar 0.839 berada dalam kategori sangat kuat dengan interval $0.81-1.00$. kemudian Nilai thitung variabel pelatihan 10.323 dan t tabel dengan sampel 47 dan taraf signifikan 0,05 diperoleh 1,678 karena t hitung > t tabel atau 10.323>1.678 maka Ha diterima. Artinya ada hubungan pelatihan dengan kinerja Badan Penanggulangan Bencana Daerah (BPBD) Kota Bandar Lampung.
\end{abstract}

Kata Kunci : Pelatihan, Kinerja Karyawan

\section{PENDAHULUAN}

Manajemen sumber daya manusia menjadi faktor penting dalam mengatur dan mengelola serta memanfaatkan pegawai agar berfungsi sesuai dengan kebutuhan organisasi, selain itu peran manajemen juga sangat dituntut untuk mempertahankan pegawai pada produktifitas tinggi dan juga pengembangan potensi pegawai agar memberikan kontribusi maksimal terhadap organisasi. Pengelolaan Sumber daya manusia secara profesional sangat diperlukan agar keseimbangan antara kebutuhan pegawai dengan tuntutan dan kemampuan organisasi dapat terjaga.

Kinerja adalah hasil kerja yang dapat dicapai oleh seseorang atau kelompok orang dalam suatu organisasi sesuai dengan wewenang dan tanggung jawab masingmasing dalam upaya pencapaian tujuan organisasi secara ilegal, tidak melanggar hukum dan tidak bertentangan dengan moral dan etika (Afandi, 2016). Dalam melakukan suatu pekerjaan setiap pegawai dituntut untuk memiliki kinerja yang tinggi.

Oleh karena itu,setiap organisasi membutuhkan pegawai yang memiliki kompetensi serta kualitas yang dapat menunjang organisasi dalam mencapai tujuan dan sasarannya. Pegawai dengan kinerja rendah akan menghambat organisasi dalam mengejar target dari organisasi tersebut. Hal ini dapat menjadi penyebab menurunnya produktivitas organisasi dikarenakan kinerja pegawai tidak sesuai dengan yang diharapkan oleh organisasi. Untuk itu manajemen perlu menelaah berbagai masalah yang dapat menjadi penyebab terjadinya penurunan kinerja tersebut. Faktor-faktor yang dapat menjadi penyebab menurunnya kinerja pegawai antara lain yang pertama faktor individu yang terdiri dari kemampuan dan 
keterampilan.(Rizal \& Pasigai, 2017). Kedua yaitu faktor psikologis yang terdiri dari persepsi, sikap, kepribadian, motivasi, kepuasan kerja dan stres kerja. Serta faktor organisasi yang terdiri dari kepemimpinan, kompensasi, konflik, kekuasaan, struktur organisasi, desain pekerjaan, desain organisasi dan karir.

Salah satu kepedulian Pemerintah pusat akan pentingnya pelatihan dan pengembangan bagi pegawai, yang mana telah diatur dalam UU Nomor 13 tahun 2003 tentang ketenagakerjaan pada bab V Pelatihan kerja pasal 9 menjelaskan pelatihan kerja diselenggarakan dan di arahkan untuk membekali, meningkatkan dan mengembangkan kompetensi kerja guna meningkatkan kemampuan, produktifitas, dan kesejahteraan.

Meskipun pelatihan dan pengembangan tenaga kerja memerlukan biaya yang tidak sedikit tetapi pelatihan dan pengembangan harus tetap dilaksanakan karena pelatihan dan pengembangan tersebut mempunyai manfaat yang besar bagi organisasi maupun pegawai organisasi tersebut. Manfaaat bagi organisasi antara lain adalah organisasi mempunyai tenaga kerja yang siap melaksanakan pekerjaannya sehingga dengan adanya tenaga kerja yang demikian organisasi dapat mencapai tujuannya dengan lebih mudah sesuai dengan visi dan misi yang ditetapkan. Badan Nasional Penanggulangan Bencana (BNPB) dan Penanggulangan Bencana Daerah (BPBD) dibentuk sesuai dengan amanat Undang-Undang Nomor 24 ahun 2007. Sebelum terbentuk BNPB dan BPBD, Satuan Kerja yang bertanggung jawab akan penyelenggaraan dan penanggulangan bencana adalah Badan Koordinasi Nasional Penanganan Bencana (Bakornas PB), akan tetapi setelah terbentuk BNPB Bakornas PB dibubarkan.

Berdasarkan Undang-Undang Nomor 24 Tahun 2007, fungsi BPBD adalah merumuskan dan menetapkan kebijakan penanggulangan bencana dan penanganan pengungsi dengan bertindak cepat, tepat, efektif dan efisien, termasuk mengkoordinasikan kegiatan penanggulangan bencana secara terencana, terpadu, dan menyeluruh. Badan Penanggulangan Bencana Daerah (BPBD) Kota Bandar Lampung merupakan salah satu instansi pemerintah yang memiliki tujuan terwujudnya profesionalisme aparatur pemerintah daerah. Oleh sebab itu

diperlukan adanya upaya pengembangan kemampuan pegawai. Yang dimaksudkan untuk mengembangkan kemampuan pegawai agar senantiasa dapat sejalan dengan perkembangan tugas pokok dan fungsinya dalam menyelesaikan pekerjaan yang diembannya.

Badan Penanggulangan Bencana Daerah (BPBD) menyelenggarakan pelatihan dan pengembangan yang dirancang untuk membekali pegawai dengan keahlian yang dibutuhkan agar dapat berprestasi. BPBD Kota Bandar Lampung dibentuk dan ditetapkan berdasarkan Peraturan Walikota Nomor 47 Tahun 2009 yang kemudian diperbaharui menjadi Peraturan Daerah Nomor 5 tahun 2010 tentang Pembentukan Badan Penanggulangan Bencana Daerah Kota Bandar Lampung dan Peraturan Walikota Nomor 70 tahun 2010 Tentang Tugas, Fungsi dan Tata Kerja Badan Penanggulangan Bencana Daerah Kota Bandar Lampung.

Tugas pokok fungsi BPBD sendiri ialah menetapkan pedoman dan pengarahan terhadap usaha penanggulangan bencana yang mencakup pencegahan bencana, penanganan darurat, rehabilitasi, serta rekontruksi secara adil dan setara, serta sebagai pihak yang mengkoordinasikan kepada satuan kerja perangkat daerah (SKPD) lainnya yang terlibat dalam 
permasalahan bencana yang terjadi di daerah tersebut(Rambe et al., 2016)

Sejak awal pembentukan Badan Penanggulangan Bencana Daerah (BPBD) telah mengikut sertakan seluruh pegawai untuk mengikuti program pelatihan dan pengembangan teknis atau biasa disebut dengan bimtek. Sebagaimana diketahui, pelatihan maupun bimbingan teknis (bimtek), merupakan kegiatan pelatihan dan pengembangan pengetahuan serta kemampuan yang dapat digunakan untuk memecahkan masalah yang dihadapi oleh setiap individu maupun institusi tertentu. Sehingga dengan mengikuti. Bimtek diharapkan setiap pegawai dapat mengambil sebuah manfaat dengan berorientasi pada prestasi kerja.

Menghadapi kenyataan bahwa semakin tingginya tingkat kompetensi yang dibutuhkan, maka tentunya pelatihan pengembangan teknis ataupun bimtek telah menjadi sebuah kebutuhan untuk setiap pegawai di lembaga pemerintahan. Bimtek lembaga pemerintahan menyajikan materi bimbingan teknis yang disesuaikan dengan kebutuhan dari lembaga pemerintahan Badan Penanggulangan Bencana (BPBD) dengan tujuan agar setelah mengikuti kegiatan bimtek ini dapat memberikan kontribusi dalam peningkatan prestasi kerja

Berdasarkan pra survey yang penulis lakukan pada Kantor Badan Penanggulangan Bencana Daerah (BPBD) Kota Bandar Lampung , observasi peneliti sementara ditemukan beberapa pegawai yang kurang produktif dalam menjalankan pekerjaannya sehingga menyebabkan pegawai pada Badan Penanggulangan Bencana Daerah (BPBD) Kota Bandar Lampung terkesan kurang menunjukkan kualitas kerjanya. Contohnya dalam penanggulangan bencana, para personil harus terlatih dan terampil dalam penanganan masalah bencana, tetapi kenyataannya para personil yang belum mengikuti pelatihan penanganan bencana/ mitigasi bencana lambat dalam mengantisipasi kemungkinan terburuk dari bencana. Permasalahan lain berupa pegawai yang telah dilatih atau telah mengikuti diklat tidak dittempatkan pada bidang kemampuan dan keahliannya seperti pegawai yang telah mengikuti diklat bencana ditempatkan di bagian keuangan, bentuk permasalahan lain berupa kesiapan personil tanggap terhadap keluhan atau aduan masyarakat mengenai bencana alam contohnya bencana banjir dan kebakaran. Permasalahan- permasalahan ini tentunya mengganggu pencapaian kinerja organisasi.

Berdasarkan penelitian sebelumnya Tentang pengaruh pelatihan kerja terhadap kinerja karyawan hasil pengujian secara parsial variabel materi pelatihan berpengaruh signifikan terhadap variabel kinerja karyawan yang dibuktikan dengan nilai signifikansi $t<\alpha(0,000<0,05)$. Hasil pengujian secara parsial variabel instruktur pelatihan berpengaruh signifikan terhadap variabel kinerja karyawan yang dibuktikan dengan nilai signifikansi $\mathrm{t} \quad<\alpha$ $(0,003<0,05)$.(Triasmoko et al., 2014)

Pelatihan terhadap Pegawai adalah hal yang mutlak diperlukan demi terciptanya produktivitas kerja yang tinggi. (Wahyuningsih, 2019). Pelatihan dilaksanakan untuk mengembangan pengetahuan, keterampilan, dan sikap pegawai agar dapat melaksanakan tugastugas pemerintahan dan pembangunan dengan sebaik-baiknya. Pelatihan dilaksanakan untuk mencapai persyaratan kompetensi teknis yang diperlukan untuk mendukung tugas pegawai sehari-hari.

Diklat teknis dilaksanakan secara berjenjang, ditetapkan oleh instansi teknis yang bersangkutan. Dari jenis pelatihan yang diberikan, dapat disimpulkan bahwa pelatihan lebih ditekankan pada sebagian aspek jenis diklat, materi, dan metode diklat harus mampu menyesuaikan dengan paradigma yang ingin dicapai sehingga dapat menjebatani kesenjangan antara 
pendidikan dan pelatihan yang diberikan dengan kebutuhan dilapangan terutama dalam mengukur keberhasilan sumber daya manusia setelah mengikuti pelatihan.

Menurut Simamora dalam Hartatik(Hartatik, 2014) pelatihan (training) merupakan proses pembelajaran yang melibatkan perolehan keahlian, konsep, peraturan, atau sikap untuk meningkatkan kinerja tenaga kerja. Dalam suatu organisasi, setiap orang memiliki peluang untuk menduduki jabatan yang tinggi dengan tujuan untuk meningkatkan kesejahteraan. Oleh karena itu diperlukan sumber daya manusia yang berkualitas serta manusia yang memiliki loyalitas yang tinggi agar tercapai produktivitas tinggi bagi organisasi. Sebuah organisasi bagaimanapun majunya teknologi yang dimiliki jika tanpa didukung oleh tenaga kerja yang cakap kemungkinan besar sasaran dari organisasi tidak akan tercapai.

Tenaga kerja yang bekerja sesuai dengan fungsinya akan menunjang tercapainya keberhasilan tujuan organisasi. Jika suatu organisasi ingin mendapatkan tenaga kerja yang terbaik untuk dapat bekerja sesuai dengan jabatan-jabatan yang ada dalam organisasi, maka penerapannya sangat ditentukan oleh sejauh mana para pegawai yang telah dipilih menunjukkan kinerja terbaiknya terhadap organisasi. Hal ini dapat diwujudkan dengan adanya program pendidikan dan pelatihan bagi pegawai. Proses pendidikan dan pelatihan merupakan upaya organisasi dalam rangka meningkatkan pengetahuan serta keterampilan pegawai, oleh karenanya hal ini perlu direncanakan dengan baik.(Harding et al., 2018). Pelatihan kerja sangat penting bagi keseimbangan perkembangan organisasi itu sendiri serta menjawab perkembangan teknologi yang kemajuannya semakin pesat.

$$
\text { Pelatihan adalah proses }
$$

pembelajaran yang ditujukan kepada karyawan agar pelaksanaan pekerjaan memuaskan (Elfrianto, 2016). Alasan diterapkannya pelatihan bagi pegawai yang baru direkrut sering kali belum memahami secara benar bagaimana melakukan pekerjaan, perubahan-perubahan dalam lingkungan kerja dan tenaga kerja, meningkatkan daya saing organisasi dan memperbaiki produktifitas pegawai. Pelatihan biasanya dimulai dengan orientasi, yakni suatu proses dimana para pegawai diberi informasi dan pengetahuan tentang kepegawaian, organisasi, dan harapanharapan untuk mencapai performance tertentu. Dalam pelatihan diciptakan suatu lingkungan dimana para pegawai dapat memperoleh atau mempelajari sikap, keahlian, dan perilaku yang spesifik yang berkaitan dengan pegawai. Pelatihan diberikan instruksi untuk mengembangkan keahlian-keahlian yang dapat langsung terpakai pada pegawai dalam rangka meningkatkan kinerja pegawai pada jabatan yang didudukinya sekarang.

Berdasarkan uraian di atas, maka dapat diangkat judul "Hubungan Pelatihan Dengan Kinerja Pegawai Badan Penanggulangan Bencana (BPBD) Kota Bandar Lampung.

\section{METODE PENELITIAN}

Jenis penelitian yang digunakan dalam penelitian ini adalah deskriptif kualitatif. Fokus permasalahan dalam penelitian ini bertujuan untuk mengetahui untuk mengetahui hubungan pelatihan dengan kinerja pegawai Badan Penanggulangan Bencana Daerah (BPBD) Kota Bandar Lampung. Metode pengumpulan data menggunakan data primer dan data skunder. Teknik pengumpulan data pada penelitian ini menggunakan teknik observasi, dokumentasi dan kuisioner atau angket.

Populasi dalam penelitian ini adalah sebanyak 237 pegawai BPBD Kota Bandar 
Lampung dan sampel yang diambil dalam penelitian ini adalah sebanyak $20 \%$ yaitu 47 orang.

Analisis data menggunakan analisis kualitatif dan kuantitatif.

Uji statistik koefisiensi korelasi product momoent $(r)$ digunakan untuk menguji atau tidaknya hubungan antara variabel bebas dengan variabel terikat. Uji hipotesis yang digunakan dalam penelitian ini adalah uji $\mathrm{t}$ yaitu membandingkan antara $t$ hitung dengan $t$ tabel. Rumusnya

$$
t_{\text {hitung }}=r \frac{\sqrt{n-2}}{\sqrt{\left(1-r^{2}\right.}}
$$

Keterangan :

$\mathrm{t}$ : Pengujian Koefisien korelasi

$\mathrm{r}$ : Koefisien korelasi

$\mathrm{n}$ : Jumlah sampel.

Tabel. 1

Kriteria Tingkat Keeratan Hubungan antara X dan Y

\begin{tabular}{cl}
\hline Nilai Korelasi & Tingkat Keeratan Hubungan \\
\hline $0.00>0.20$ & Lemah \\
$0.21>0.40$ & Rendah \\
$0.41>0.60$ & Sedang \\
$0.61>0.80$ & Kuat/ Tinggi \\
$0.81>1.00$ & Sangat Kuat / Sangat Tinggi \\
\hline
\end{tabular}

Sumber : (Sugiyono, 2013)

\section{HASIL DAN PEMBAHASAN}

Berdasarkan hasil penelitian yang dilakukan tentang hubungan pelatihan dengan kinerja pegawai Badan Penanggulangan Bencana Daerah (BPBD) Kota Bandar Lampung diperoleh hasil sebagai berikut:

Berdasarkan hasil analisis kualitatif diperoleh bahwasannya hasil angket tentang pelatihan diperoleh hasil sebagai berikut : sebanyak 16 responden (34\%) menjawab sangat setuju, 13 responden (28\%) menjawab setuju, sebanyak 15 responden $(31 \%)$ menjawab kurang setuju, dan sisanya sebanyak 3 responden (7\%) menjawab tidak setuju dengan penerapan pelatihan di BPBD Kota Bandar Lampung.

Berdasarkan hasil angket tentang kinerja diperoleh hasil sebagai berikut : rata-rata Sebanyak 17 responden (36\%) menjawab sangat setuju, 9 responden $(19 \%)$ menjawab setuju, 18 responden (38\%) menjawab kurang setuju dan sisanya sebanyak 4 responden $(8 \%)$ menjawab tidak setuju dengan kriteria kinerja yang ada di BPBD Kota Bandar Lampung.

Hasil dari penghitungan statistik hubungan Pelatihan dengan kinerja dapat terlihat pada tabel berikut : 


\begin{tabular}{|c|c|c|c|}
\hline & & Pelatihan & Kinerja \\
\hline \multicolumn{2}{|c|}{ Pelatihan Pearson Correlation } & 1 & $.839^{* *}$ \\
\hline \multirow{2}{*}{\multicolumn{2}{|c|}{ Sig. (2-tailed) N }} & & .000 \\
\hline & & 47 & 47 \\
\hline \multirow[t]{3}{*}{ Kinerja } & Pearson Correlation & $.839^{* *}$ & 1 \\
\hline & \multirow[t]{2}{*}{ Sig. (2-tailed) $\mathrm{N}$} & .000 & \\
\hline & & 47 & 47 \\
\hline
\end{tabular}

**. Correlation is significant at the 0.01 level (2-tailed)

sebesar 0.839 berada dalam kategori sangat

Dari tabel di atas terlihat nilai hubungan antara pelatihan dengan kinerja pegawai BPBD Kota Bandar Lampung sebesar 0,839. Artinya ada hubungan pelatihan dengan kinerja. Kemudian nilai kuat dengan interval $0.81-1.00$.

Dengan demikian berdasarkan tingkat kreteria tingkat keeratan maka tingkat keeratan hubungan pelatihan kerja termasuk keeratan hubungan pelatihan dan kinerja

Tabel. 11 Pengujian Hubungan Pelatihan dengan Kinerja menggunakan Uji t

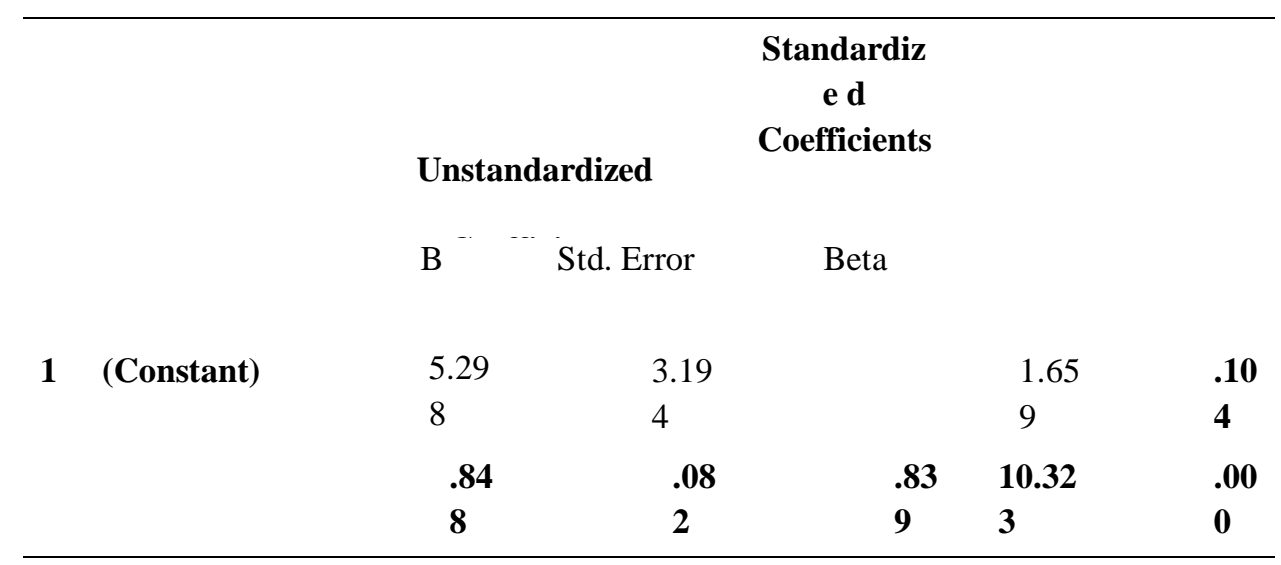

a. Dependent Variable: Kinerja

Nilai $\mathrm{t}$ hitung variabel pelatihan 10.323 dan $t$ tabel dengan sampel 47 dan taraf signifikan 0,05 diperoleh 1,678 karena t hitung $>$ t tabel atau $10.323>1.678$ maka Ha diterima.

\section{Pembahasan}

Untuk menciptakan sumber daya manusia yang berkualitas dibutuhkan pelatihan yang dapat meningkatkan kualitas kinerja dari sumber daya manusia. Menurut Rachmawati pelatihan merupakan penguasaan keterampilan dan teknik pelaksanan kerja pada bidang tertentu, terinci, dan rutin." Pelatihan menyiapkan para karyawan untuk melaksanakan pekerjaan-pekerjaan yang sudah ada dan pekerjaan yang baru diberikan oleh perusahan. Untuk itulah pelatihan dibuat 
agar dapat membantu perusahaan dalam mencapai tujuan dari perusahaan tersebut.

Lebih lanjut Syihabuddin Qalyubi, dkk dalam Hasan menjelaskan bahwa pelatihan merupakan suatu upaya pengembangan sumber daya manusia dalam sebuah organisasi termasuk perpustakaan. Kegiatan pelatihan dimaksudkan untuk memperbaiki dan mengembangkan keterampilan serta kemampuan teknis parapegawai/karyawan.(Hasan, 2018).

Pelatihan biasanya dimulai dengan orientasi, yakni suatu proses dimana para pegawai diberi informasi dan pengetahuan tentang kepegawaian, organisasi, dan harapan-harapan untuk mencapai performance tertentu. Dalam pelatihan diciptakan suatu lingkungan dimana para pegawai dapat memperoleh atau mempelajari sikap, keahlian, dan perilaku yang spesifik yang berkaitan dengan pegawai.

Hasil penelitian yang dilakukan oleh Sandhy, Maulana Kurnia; Irfani, Aminuddin Tahun 2019 dengan judul Pengaruh Pelatihan terhadap Kinerja Karyawan pada PT. Rekatama Putra Gegana Bandung bahwa Pelatihan berpengaruh signifikan terhadap kinerja karyawan PT.Rekatama Putra Gegana Bandung.(Sandhy \& Irfani, 2018)

Kemudian penelitian yang dilakukan oleh Denny Triasmoko Tahun 2014 dengan judul Pengaruh Pelatihan Kerja Terhadap Kinerja Karyawan PT Pos Indonesia (Persero) Cabang Kota Kediri membuktikan bahwa secara parsial variabel metode pelatihan berpengaruh signifikan terhadap variabel kinerja karyawan yang dibuktikan dengan nilai signifikansi $\mathrm{t}<\alpha(0,009<0,05)$. Hasil pengujian secara parsial variabel materi pelatihan berpengaruh signifikan terhadap variabel kinerja karyawan yang dibuktikan dengan nilai signifikansi $\mathrm{t}<\alpha$ $(0,000<0,05)$. Hasil pengujian secara parsial variabel instruktur pelatihan berpengaruh signifikan terhadap variabel kinerja karyawan yang dibuktikan dengan nilai signifikansi $\mathrm{t}<\alpha(0,003<0,05)$.

Dengan demikian hal ini sejalan dengan hasil penelitian yang peneliti lakukan bahwasannya dari hasil uji korelasi bahwa keeratan hubungan pelatihan dan kinerja sebesar 0.839 berada dalam kategori sangat kuat dengan interval $0.81-1.00$. kemudian Nilai thitung variabel pelatihan 10.323 dan $\mathrm{t}$ tabel dengan sampel 47 dan taraf signifikan 0,05 diperoleh 1,678 karena $t$ hitung > t tabel atau 10.323>1.678. hal ini membuktikan bahwasannya pelatihan dan kinerja pegawai di Badan Penanggulangan Bencana Daerah Kota Bandar Lampung memiliki hubungan yang kuat.

\section{KESIMPULAN}

Berdasarkan hasil penelitian tentang hubungan pelatihan dan kinerja pegawai BPBD Daerah kota Bandar Lampung diperoleh kesimpulan sebagai berikut: Hasil pengujian hipotesis hubungan pelatihan dengan kinerja menunjukan bahwa nilai hubungan antara pelatihan dengan kinerja pegawai BPBD Kota Bandar Lampung sebesar 0,839. Artinya ada hubungan pelatihan dengan kinerja. Kemudian nilai keeratan hubungan pelatihan dan kinerja sebesar 0.839 berada dalam kategori sangat kuat dengan interval $0.81 \quad-1.00$ yang memiliki arti bahwasnnya tingkat keeratan hubungannya kuat. Kemudian Nilai t hitung variabel pelatihan 10.323 dan $t$ tabel dengan sampel 47 dan taraf signifikan 0,05 diperoleh 1,678 karena thitung > t tabel atau 
$10.323>1.678$ maka Ha diterima. Dengan demikian artinya ada hubungan pelatihan dengan kinerja Badan Penanggulangan Bencana Daerah (BPBD) Kota Bandar Lampung.

\section{DAFTAR PUSTAKA}

Afandi, P. (2016). Concept \& Indicator Humana Resources Management For Management Research. Deepublish.

Elfrianto. (2016). Manajemen Pelatihan Sumber Daya Manusia Dalam Meningkatkan Mutu Lulusan. Jurnal Edutech, Vol 2 No. 2.

Harding, D., Kadiyono, A. L., Hidayat, Y., \& Yanuarti, N. (2018). Pelatihan Dan Pengembangan Sdm Sebagai Salah Satu Upaya Menjawab Tantangan Mea. Journal Of Psychological Science And Profession, $2(2), \quad 185$. Https://Doi.Org/10.24198/Jpsp.V2i2 .21196

Hartatik, I. P. (2014). Buku Praktis Mengembangkan Sdm. Laksana.

Hasan, N. A. (2018). Pendidikan Dan Pelatihan Sebagai Upaya Peningkatan Kinerja Pustakawan. 10(1), 21.

Rambe, A., Purba, A., \& Tarigan, U. (2016). Analisis Pemberdayaan Pegawai Badan Penanggulangan Bencana Daerah Kota Medan. 11.

Rizal, S., \& Pasigai, M. A. (2017). Analisis Faktor Yang Mempengaruhi Kinerja Pegawai Pada Sekretariat Komisi Penyiaran Indonesia Daerah Sulawesi Selatan. 5, 10.
Sandhy, M. K., \& Irfani, A. (2018). Pengaruh Pelatihan Terhadap Kinerja Karyawan Pada Pt. Rekatama Putra Gegana Bandung. Prosiding Manajeman Spesia, 4(2), 5.

Sugiyono. (2013). Metode Penelitian Kuantitatif, Kualitatif Dan $R \& D$. Alfabeta.

Triasmoko, D., Mukzam, M. D., \& Nurtjahjono, G. E. (2014). Pengaruh Pelatihan Kerja Terhadap Kinerja Karyawan. Jurnal Administrasi Bisnis, Vol 12. No 1, 10.

Wahyuningsih, S. (2019). Pengaruh Pelatihan Dalam Meningkatkan Produktivitas Kerja Karyawan. 16. 